\title{
FDI, ECONOMIC FREEDOM AND ECONOMIC GROWTH OF NIGERIA
}

\author{
${ }^{* 1}$ Sekunmade J.O. \\ "Department of Economics and Finance, Istanbul Gelisim University (IGU), Istanbul, Turkey \\ "Corresponding Author Email: dammyjoh@gmail.com Phone: +905526749909
}

\begin{abstract}
This paper investigates Foreign Direct Investment, Economic Freedom and Economic Growth of Nigeria between 1995 and 2018. Specifically, the data on: Foreign Direct Investment (FDI) inflows, Economic Freedom (Aggregate index) and the data on real gross domestic product (RGDP) were used during the analysis. Time-series data were tested for stationarity using the Augmented Dickey-Fuller Unit Root test method. Vector Autoregressive (VAR) estimation method was adopted to examine the effect of FDI, Economic Freedom on Economic growth. The interactive effect of FDI and Economic Freedom on Economic growth was determined using regression analysis while Granger Causality test method was adopted for determining the causality relationship among the variables. The result of the Vector Autoregressive (VAR) suggests that both FDI and Economic freedom do not have a significant effect on economic growth in Nigeria. The result of regression analysis shows that the joint coefficient of both FDI and EF is negative and not significant. The result of Granger Causality revealed that there is a uni-directional relationship between RGDP and FDI and between EF and FDI respectively. The research recommends that the federal government of Nigeria should adopt appropriate foreign trade strategies to enhance the impact of FDI on economic growth in Nigeria.
\end{abstract}

Keywords: Economic Freedom, Economic Growth, Foreign Direct Investment, Time Series, Unit Root, Uni-directional

LICENSE: This work by Open Journals Nigeria is licensed and published under the Creative Commons Attribution License 4.0 International License, which permits unrestricted use, distribution, and reproduction in any medium, provided this article is duly cited.

COPYRIGHT: The Author(s) completely retain the copyright of this published article.

OPEN ACCESS: The Author(s) approves that this article remains permanently online in the open access (OA) model.

QA: This Article is published in line with "COPE (Committee on Publication Ethics) and PIE (Publication Integrity \& Ethics)". 


\section{INTRODUCTION}

Developing economies, particularly Africa are always in deficit of investible funds, which makes preference for foreign investment and/or national savings to fill the gap (Ariyo, 1998). It has been observed through the past studies that countries with modern infrastructures such as good road, pipe borne water, stable electricity etc. has a higher tendency of pulling FDI inflow because this has been a pivotal role in motivating foreign investors coupled with excess cheap labor which include both skilled and unskilled which eventually attracts FDI, cost cutting and efficiency seeking among foreign investors (Pan-Long, 2014).

Economic Freedom, FDI and price intercalary elements of GDP in central, Japanese and Western European countries were studied by Sayari et al. (2018) and de Haan and Stum (2000) to determine long run association among these variables. Evidence showed slightly importance plus negative association between FDI and Economic freedom when random effect model was adopted at intervals. Considering the influential role FDI plays in trajectory of growth and economic modifications, emerging economies are now altering their trade policies, building favorable institutional frameworks to support the workability of the FDI arrangements (Ayanwale, 2007).

In producing European industries, FDI on productivity growth was analyzed by Ubeda and Perez-Hernandez (2017); (Becker et al. (1990) and Doucouliagos and Ulubasoglu (2006). A theoretical model was adopted to examine the non-linear relationship that exists between FDI inflow and improvement in domestic corporations' productivity. Several past studies have shown concerns on how FDI transforms into economic growth in Nigeria. One of the growing controversies is FDI direct impact on growth is argued to be conditional upon certain mediation link. While institutional framework plays a significant role, economic freedom has consistently been argued to play important major role on the other.

In Asia countries between 1980-2010, Chen and Zulkifli (2012) carried out a research to know the extent of relationship between FDI outflow and Economic growth. Using a VECM, it was observed that there was long relationship between Economic growth and FDI conjointly plus a long bi-directional association. Evidence also showed that at intervals in the short run, there was absence of Granger-Causality between FDI outflow and Economic growth. The growth analyst has given a verdict that there tends to be a rapid growth and attraction of more FDI among countries that have a soft spot for Economic freedom which invariably leads to Economic development. Ayal and Karras (1998).

\section{STATEMENT OF THE PROBLEM}

Evidence has shown that many studies have been done in the past on (FDI) impact on growth in an economy, as well as Freedom in economy impacting Economic Growth but, research paucity exist on likelihood for economic freedom to play a significant role on FDI impacting Economic Growth. With this background information, there is shifted attention to show how much of interaction exist between Economic freedom and FDI to achieve the desirable Economic growth.

Meanwhile, the focus of many past studies has been on states within economic regions. Sovbetov and Moussa (2017); and Hussain and Haque (2016) are examples of such studies. There have been scarce studies to focus on Nigeria only. Another important observed problem intensifying the interest in this current study is the mixed findings 
of past extant studies which continually makes it difficult for policy formulation. For instance, Ogbonna et al. (2012) findings show that, FDI though; causes $13 \%$ variation in GDP yet remains insignificant.

Also, the years of research in the past extant studies used different timeframe. Ajide and Eregha (2015) information stops at 2015 but the current study ends in 2018 and it is peculiar to Nigeria. Based on these identified problems, the need to address the interaction among the variables becomes important.

\section{RESEARCH QUESTIONS}

i. How does Economic Growth affect FDI and Economic Freedom?

ii. How does the interactive effect of both FDI and Economic independence impact Economic Growth?

iii. Among the variables, what causal relation exists?

\section{OBJECTIVES OF THE STUDY}

The overall aim basically studies connection between Nigeria's Foreign Direct Investment, Economic Freedom and Economic Growth (1995-2018). However, specific objectives are to:

i. discover FDI and Economic independence effects on Nigeria's Economic Growth.

ii. study interactive Economic influence of FDI and Economic independence on Nigeria's Economic Growth.

iii. analyze causal relationship that exist among FDI, Economic Freedom and Nigeria Economic Growth.

\section{RESEARCH HYPOTHESES}

$\mathrm{H}_{01}$ : Economic Freedom and FDI do not significantly affect Nigeria Economic Growth.

$\mathrm{H}_{02}$ : FDI and Economic Freedom have no significant interactive effect on Economic Growth.

$\mathrm{H}_{03:}$ There are no causal relationship among FDI, Economic Freedom and Nigeria Economic Growth.

\section{SIGNIFICANCE OF THE STUDY}

There is hope in contributing enormously to existing research work on mixed results from past related studies. More so, findings from the study can be useful for policy formulation. Government agencies, researchers and investors can as well find this type of study useful particularly as an eye-opener in describing how FDI and Economic Freedom can impact on Nigeria Economic Growth.

\section{MATERIALS AND METHODS}

Data spanning from 1995 to 2018 i.e. time series was integrated. The data on: Foreign Direct Investment (FDI) inflows and Real Gross Domestic Product (RGDP) were sourced through CBN Statistical Bulletin. Economic Freedom (Aggregate index) data was sourced from Heritage Foundation (www.heritage.org/index/visualize). The variables adopted for measuring FDI and Economic Freedom effect on Nigeria's Economic Growth was adapted following Ajide and Eregha (2015). Economic Growth was proxy as Real Gross Domestic Product, FDI inflow and Economic Freedom (overall index) from $1995-2018$. 
An inferential statistical technique was adopted as method of analysis. Firstly, Augmented Dickey-Fuller Unit Root test method showed datasets integration order. Upon confirmation of the series to be order one integrated, this prompted the use of Johansen Juselius cointegration test method which was introduced by a Danish Statistician and Econometrician who is known for his contributions to the theory of cointegration. However, there was no cointegrating equation which prompted the need to use Vector Autoregressive (VAR) estimation method. This assisted to discover FDI and economic freedom effects on Nigeria economic growth i.e. first objective.

To show the interactive Economic influence of FDI and Economic independence i.e. second objective, regression analysis was adopted while Granger Causality test method was adopted for determining the causality relationship among the variables which is the third objective.

\section{MODEL SPECIFICATION}

Adopted model was from Ajide and Eregha (2015) and is moderated to suit the need of this current study. Simple endogenous growth model was considered which indicates that:

$R G D P=f\left(A K^{\alpha} L^{\beta}\right)$.

Whereas;

$R G D P$ denotes Real Gross Domestic Product proxy for Economic Growth;

$A$ denotes total factor productivity which comprises the export trade (ET);

$K$ denotes human capital stock;

$L$ denotes labour.

Considering the theoretical thinking of the Simple Endogenous Model and the Dunning's Eclectic Theory, it can be reasonably assumed that:

$R G D P=f($ Foreign Direct Invetment, Economic Freedom $)$ 3.2

Equation 3.2 above assumes the theoretical linkage of FDI, Economic Freedom and Economic Growth in Nigeria. Thus, considering factors endowment plus available institutional framework for attracting FDIs, Nigeria has the tendency to achieve economic growth.

In mathematical terms, model 3.2 can be expressed as thus;

$R G D P=\beta_{0}+\beta_{1} F D I+\beta_{2} E F+\mathrm{e}$

Where;

$\beta_{0}$ denotes the intercept i.e. the constant term,

$\beta_{1}$, and $\beta_{2}$ denote the model parameters, and

FDI denotes total Foreign Direct Investment inflows (in billions)

EF denotes Economic Freedom,

When converted to econometrics and logarithm, then equation 3.3 becomes;

$\operatorname{InRGDP}=\beta_{0}+\beta_{1} \operatorname{InFDI}+\beta_{2} \operatorname{InEF}+e$

Meaning;

In denotes the natural logarithm,

$e$ denotes error Term or the residual 
Equation 3.4 can now be specified in time series form as;

$\operatorname{In}(R G D P)_{t}=\beta_{0}+\beta_{1} \operatorname{InFDI}_{t}+\beta_{2} \operatorname{InEF}_{t}+e$

Where;

t represents the number of years.

\section{A PRIORI EXPECTATION}

Based on the economic theory, expectancy of positive relationship which is direct is envisaged between FDI, economic freedom and real GDP. More FDI and economic freedom generate an increment in real GDP based on assumption. (i.e. $\beta_{1}, \beta_{2}>0$ ).As for the intercept (constant term), the sign effect can be positive or negative. (i.e. $\beta_{0}>$ or $<0$ ).

\section{RESULTS AND DISCUSSION}

The results of the inferential statistics were discussed in a bid to give knowledge and give clearer thought on the research objectives. Different Econometrics models were adopted to show the significant level of the data in the study.

\section{UNIT ROOT TEST}

Unit root result test is presented below. It indicates that all the series (i.e. Real GDP, FDI inflow and EF) were not stationary at level hence, thus containing unit root. But the series was stationary when differenced at first order, which implies I (1) series. See (table I) below

Table I: Unit Root Test Result

\begin{tabular}{lllll}
\hline & ADF & Critical Value @ 5\% & Prob. & Remarks \\
\hline InRGDP & & & & \\
Level & -1.2698 & -3.0049 & 0.6245 & \\
$1^{\text {st }}$ Difference & -5.1925 & -3.0125 & 0.0005 & $\mathrm{I}(1)$ \\
& & & & \\
FDI inflow & & & & \\
Level & -3.1411 & -3.0299 & 0.0403 & \\
$1^{\text {st }}$ Difference & -4.1996 & -3.0049 & 0.0038 & $\mathrm{I}(1)$ \\
& & & & \\
EF & & & & \\
Level & -1.7874 & -2.9981 & 0.3769 & \\
$1^{\text {st }}$ Difference & -5.0227 & -3.0049 & 0.0006 & $\mathrm{I}(1)$ \\
& & & & \\
\hline
\end{tabular}

Source: Researcher's Computation from estimates ran on Eviews 10

\section{COINTEGRATION TEST}

Since the series have been confirmed to be I (1) series, it shows that there is likelihood for the series to have long-run relationship. Therefore, to confirm this, cointegration test was run using Johansen Juselius test method. The result is presented through table (II) below. The cointegration test result reveals is no cointegrating equation among the series which prompted estimating Vector Autoregressive models from the series. 


\section{Table II: Cointegration Test Result}

Sample (adjusted): 19942018

Included observations: 23 after adjustments

Trend assumption: Linear deterministic trend

Series: EF FDI LNRGDP

Lags interval (in first differences): 1 to 1

Unrestricted Cointegration Rank Test (Trace)

\begin{tabular}{lllll}
\hline \hline $\begin{array}{l}\text { Hypothesized } \\
\text { No. of CE(s) }\end{array}$ & Eigenvalue & $\begin{array}{l}\text { Trace } \\
\text { Statistic }\end{array}$ & $\begin{array}{l}0.05 \\
\text { Critical Value }\end{array}$ & Prob.** \\
\hline \hline None & 0.398668 & 23.71202 & 29.79707 & 0.2129 \\
At most 1 & 0.154717 & 6.927978 & 15.49471 & 0.5860 \\
At most 2 & 0.040991 & 1.381194 & 3.841466 & 0.2399 \\
\hline \hline
\end{tabular}

Trace test indicates no cointegration at the 0.05 level

* denotes rejection of the hypothesis at the 0.05 level

**MacKinnon-Haug-Michelis (1999) p-values

Unrestricted Cointegration Rank Test (Maximum Eigenvalue)

\begin{tabular}{lllll}
\hline \hline $\begin{array}{l}\text { Hypothesized } \\
\text { No. of CE(s) }\end{array}$ & Eigenvalue & $\begin{array}{l}\text { Max-Eigen } \\
\text { Statistic }\end{array}$ & $\begin{array}{l}0.05 \\
\text { Critical Value }\end{array}$ & Prob.** \\
\hline \hline None & 0.398668 & 16.78405 & 21.13162 & 0.1824 \\
At most 1 & 0.154717 & 5.546784 & 14.26460 & 0.6718 \\
At most 2 & 0.040991 & 1.381194 & 3.841466 & 0.2399 \\
\hline \hline
\end{tabular}

Max-eigenvalue test indicates no cointegration at the 0.05 level

$*$ denotes rejection of the hypothesis at the 0.05 level

**MacKinnon-Haug-Michelis (1999) p-values

Source: Researcher's Computation from estimates ran on Eviews 10

\section{VECTOR AUTOREGRESSIVE MODEL TEST}

Because no cointegrating equation exists between the series, the next estimation technique adopted was vector autoregressive (VAR) model. The optimal length of lag for the test thus, calculated through presented criteria on table (III) below. The optimal length of lag needed for the VAR model test given by criteria, taking into account Akaike Information criterion (AIC) and Schwarz Criterion will be 1year which is hereby adopted for the testing.

\section{Table III: Optimal Lag Length}

Endogenous variables: LNRGDP FDI EF

Exogenous variables: $\mathrm{C}$

Sample: 19952018

Included observations: 24 


\begin{tabular}{lllllll}
\hline \hline Lag & LogL & LR & FPE & AIC & SC & HQ \\
\hline \hline 0 & -141.9431 & NA & 2.310818 & 9.351165 & 9.489938 & 9.396402 \\
1 & -44.03769 & $170.5449 *$ & $0.007492^{*}$ & $3.615335^{*}$ & $4.170426^{*}$ & $3.796281^{*}$ \\
2 & -39.63264 & 6.820710 & 0.010275 & 3.911784 & 4.883194 & 4.228439 \\
3 & -39.01572 & 0.835835 & 0.018512 & 4.452627 & 5.840357 & 4.904992 \\
4 & -35.11499 & 4.529881 & 0.028249 & 4.781612 & 6.585661 & 5.369687 \\
\hline \hline
\end{tabular}

* indicates lag order selected by the criterion

LR: sequential modified LR test statistic (each test at 5\% level); FPE: Final Prediction Error

AIC: Akaike information criterion; SC: Schwarz information criterion; HQ: Hannan-Quinn information criterion

Source: Researcher's Computation from estimates ran on Eviews 10

Vector Autoregressive Model result estimates (table IV below)

Table IV: Vector Autoregressive Model Result

Sample (adjusted): 19942018

Included observations: 23 after adjustments

Standard errors in ( ) \& t-statistics in [ ]

\begin{tabular}{lccc}
\hline \hline & LNRGDP & FDI & EF \\
\hline \hline DLNRGDP(-1) & 0.892790 & -0.006901 & 0.034936 \\
& $(0.09921)$ & $(0.04038)$ & $(0.04200)$ \\
& {$\left[\begin{array}{l}{[8.99898]} \\
{[-0.17090]}\end{array}\right.$} & {$[0.83189]$} \\
DFDI(-1) & -0.099348 & 0.950221 & 0.391573 \\
& $(0.24744)$ & $(0.10071)$ & $(0.10474)$ \\
& {$[-0.40150]$} & {$[9.43556]$} & {$[3.73840]$} \\
DEF(-1) & 0.186968 & 0.000420 & 0.682694 \\
& $(0.21162)$ & $(0.08613)$ & $(0.08958)$ \\
& {$[0.88352]$} & {$[0.00488]$} & {$[7.62125]$} \\
C & & & \\
& 0.069578 & 0.369684 & 0.623813 \\
& $(0.48054)$ & $(0.19558)$ & $(0.20342)$ \\
\hline \hline R-squared & {$[0.14479]$} & {$[1.89024]$} & {$[3.06670]$} \\
Adj. R-squared & 0.883314 & 0.975856 & 0.986002 \\
Sum sq. resids & 0.871645 & 0.973441 & 0.984603 \\
S.E. equation & 16.51864 & 2.736113 & 2.959884 \\
F-statistic & 0.742039 & 0.302000 & 0.314106 \\
Log likelihood & 75.70005 & 404.1791 & 704.4119 \\
Akaike AIC & -35.97210 & -5.406931 & -6.743331 \\
Schwarz SC & 2.351300 & 0.553349 & 0.631961 \\
Mean dependent & 2.530872 & 0.732921 & 0.811532 \\
S.D. dependent & 6.696837 & 3.339264 & 6.168320 \\
\hline \hline
\end{tabular}

Determinant resid covariance (dof adj.) $\quad 0.004744$

Determinant resid covariance $\quad 0.003259$ 
Log likelihood

Akaike information criterion

Schwarz criterion
$-47.38296$

3.493115

4.031831

Source: Researcher's Computation from estimates ran on Eviews10

\section{INTERPRETING THE VAR RESULT}

From the VAR estimates output, it would be deduced that the RGDP VAR model is fit at $\mathrm{R}^{2}=88.3 \%$, Foreign Direct Investment Inflow (FDI) VAR model is fit at $\mathrm{R}^{2}=97.5 \%$, and Economic Freedom (EF) model is fit at $\mathrm{R}^{2}=98.6 \%$. EF VAR model's F-statistics is more robust than others with RGDP being the least.

To determine which model to choose, we make reference to model specification mentioned earlier.

$$
\operatorname{lnRGPP}_{t-1}=0.069578-0.099348 F D I_{t-1}+0.186968 E F_{t-1}
$$

By reading from the model selected, it would be noticed that the sign of the slope coefficients of FDI is not in conformity with a priori expectation but the 1-period lag of $\mathrm{EF}$ is in conformity.

The FDI not being in conformity with a priori expectation might possible be as a result of Investors square measure attracted by high expected returns on their investment, conjointly as a causative, favorable term of trade and dealing condition, internal institutional structures cannot also be underestimated. All these are not absolutely in place in Nigeria. The government of Federal Republic of Nigeria should be woke up and certify that the social infrastructures square measure created conjointly as political stability and this might spur the foreign investors to possess interest in finance in Nigeria Economy which might have a multiplier factor result on the economy at intervals in the long run. The Economic freedom as pictured from the model is in conformity with a priori expectation; this shows that there are square measure policies in place that commit to open the economy for foreign investors. Government of Nigeria ought to certify that there is effectiveness to harness this goal so as that there will be a positive response and urge for finance at intervals in the economy by foreign investors.

Any $1 \%$ change (rise) in value of 1-period lag of FDI will bring about $0.099348 \%$ short-run elasticity effect (fall) on RDGP at time $t$. However, any 1unit change (rise) in a 1-period lag of EF will bring about 0.186968 unit short-run inelasticity effect (rise) on RGDP at time $t$.

\section{DECISION}

The result shows that both FDI and Economic Freedom do not significantly affect Nigeria Economic Growth hence, the null hypothesis $\left(\mathrm{H}_{01}\right)$ would be accepted while we will reject the alternate hypothesis.

\section{DIAGNOSTIC TESTS}

Two types of diagnostic tests were run on the VAR estimates reported above. These include the VAR Residual Normality Tests and the AR Roots (both the Graph and Table). VAR Residual Normality test result (Table V) while the AR Roots were presented (Table VI) and Figure IV below) 
Table V: VAR Residual Normality Test

Orthogonalization: Cholesky (Lutkepohl)

Null Hypothesis: residuals are multivariate normal

Sample: 19952018

Included observations: 24

\begin{tabular}{lllll}
\hline \hline Component & Skewness & Chi-sq & Df & Prob. \\
\hline \hline 1 & 4.939643 & 138.2671 & 1 & 0.1560 \\
2 & 2.702338 & 41.38158 & 1 & 0.3120 \\
3 & 1.864387 & 19.69700 & 1 & 0.1132 \\
\hline \hline Joint & & 199.3456 & 3 & 0.2243 \\
\hline \hline Component & Kurtosis & Chi-sq & Df & Prob. \\
\hline \hline 1 & 27.56395 & 854.7990 & 1 & 0.3601 \\
2 & 11.91192 & 112.5150 & 1 & 0.2500 \\
3 & 8.121288 & 37.15575 & 1 & 0.1736 \\
\hline \hline Joint & & 1004.470 & 3 & 0.1141 \\
\hline \hline Component & Jarque-Bera & Df & Prob. & \\
\hline \hline 1 & 993.0660 & 2 & 0.2611 & \\
2 & 153.8966 & 2 & 0.1094 & \\
3 & 56.85274 & 2 & 0.0831 & \\
\hline \hline Joint & 1203.815 & 6 & 0.2254 & \\
\hline \hline
\end{tabular}

Source: Researcher's Computation from estimates ran on Eviews10

The residual normality test result (Table $\mathrm{V}$ above), the sequence from which the Jarque-Bera statistics results were calculated shows skewness and kurtosis. From the result of the skewness of the series, the probability value of 0.2243 indicates that the series were well skewed. More so, the Kurtosis result also showed that the series were not flattened. The Joint Jarque-Bera statistics finally confirmed that the series are all normally distributed.

Table VI: Autoregressive (AR) Roots Table

Endogenous variables: LNRGDP FDI EF

Exogenous variables: $\mathrm{C}$

Lag specification: 11

\begin{tabular}{ll}
\hline \hline \multicolumn{1}{c}{ Root } & Modulus \\
\hline \hline $0.938724-0.030117 \mathrm{i}$ & 0.939207 \\
$0.938724+0.030117 \mathrm{i}$ & 0.939207 \\
0.648257 & 0.648257 \\
\hline \hline
\end{tabular}


No root lies outside the unit circle.

VAR satisfies the stability condition.

Source: Researcher's Computation from estimates ran on Eviews 10

Inverse Roots of AR Characteristic Polynomial

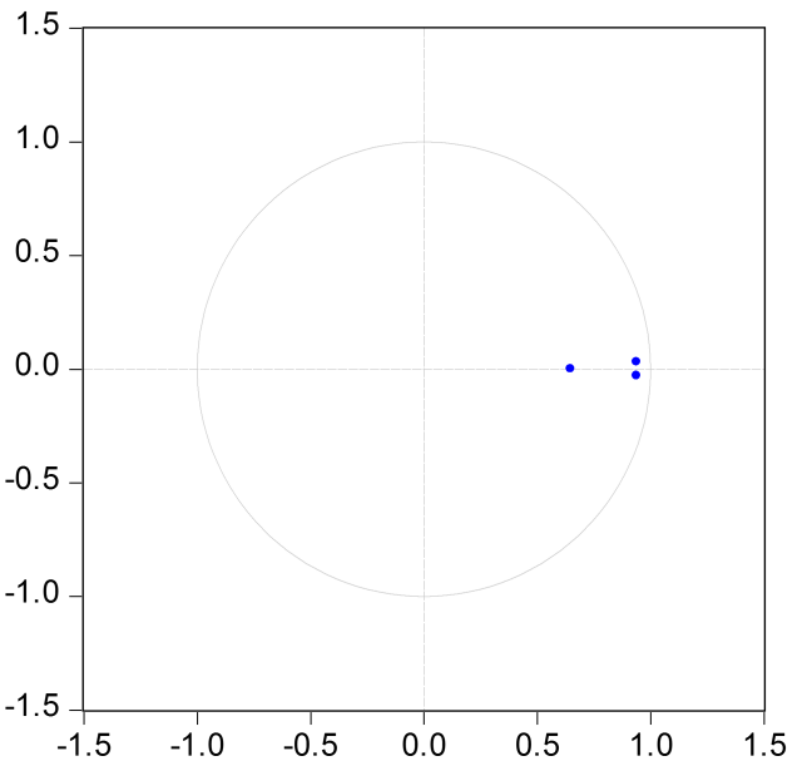

Figure I: AR Roots Graph

Source: Researcher's Computation from VAR estimates ran on Eviews10

The AR Roots result presented above describe the inverse roots of the characteristics AR polynomial. For an estimated VAR to be said to be stable, roots modulus must be less than one and be in the confinement of the unit circle. Drawing from the AR Roots test result, from (Table VI), it can be deduced that all the roots have their Modulus lesser than one and also, in confinement of the unit circle on Figure (I) hence, the VAR model estimated in Table (IV) above is stable and is suitable for policy making.

\section{REGRESSION ANALYSIS}

Since the series have been confirmed to be order one i.e. I (1), the regression analysis result is shown (table VII) below. It depicts how the Economic growth is affected by the interactive effect of both FDI and Economic Freedom. The joint coefficient of both FDI and EF are negative - 0.015156 . Also, the probability value of 0.4563 shows that it is not significant. As such, we will accept null hypothesis $\left(\mathrm{H}_{02}\right)$ while reject the alternate hypothesis.

The negative sign from the statistical method reveals poor mediation linkage between Nigeria's FDI and Economic Freedom respectively. As asserted in the eclectic paradigm theory in social science i.e. OLI-Model. John H. Dunning (1979) postulates that there are three advantages to get pleasure from by partaking in Foreign Direct 
Investment. These include; Ownership Advantage, Location Advantage, Internalization Advantage.

Having a strong affinity and assurance that the strategies that have been productive in sustaining the core competence value of the organization will be viable in cross-border markets will spur firms to invest in foreign markets. In the context of Nigeria Economy, the aforementioned factors are still wobbling and as a result, there is high impediment towards growth process. The factors require utmost priority and well-structured strategies by the Nigeria government to strengthen positive link between FDI influx and Economic freedom at intervals in the country.

\section{Table VII: Regression Analysis Test Result}

Dependent Variable: D(LOGRGDP)

Method: Least Squares

Sample (adjusted): 19962018

Included observations: 23 after adjustments

\begin{tabular}{lllll}
\hline \hline Variable & Coefficient & Std. Error & t-Statistic & Prob. \\
\hline \hline C & 0.056640 & 0.007521 & 7.531110 & 0.0000 \\
D(LOGFDI_EF) & -0.015156 & 0.019930 & -0.760453 & 0.4563 \\
\hline \hline R-squared & 0.029537 & Mean dependent var & 0.057393 \\
Adjusted R-squared & -0.021540 & S.D. dependent var & 0.033803 \\
S.E. of regression & 0.034165 & Akaike info criterion & -3.824833 \\
Sum squared resid & 0.022178 & Schwarz criterion & -3.725354 \\
Log likelihood & 42.16074 & Hannan-Quinn criter. & -3.803243 \\
F-statistic & 0.578289 & Durbin-Watson stat & 0.674032 \\
Prob(F-statistic) & 0.456318 & & \\
\hline \hline
\end{tabular}

Source: Researcher's Computation from estimates ran on Eviews 10

\section{CAUSAL RELATIONSHIP TEST}

The result of Granger causality (Table VIII below) revealed that FDI does not granger cause LOGRGDP, we accept the null hypothesis with probability value 0.2962 . But, LOGRGDP granger causes FDI, the null hypothesis is rejected as indicated by probability value 0.0985 ( $\mathrm{p}<0.10)$. This indicates one-way causation flowing from LOGRGDP to FDI. Therefore, the alternate hypothesis is accepted meaning a uni-directional relationship exists between LOGRGDP and FDI.

EF does not granger cause LOGRGDP, we accept null hypothesis with probability value 0.4156 . Also, LOGRGDP does not granger cause EF, we accept null hypothesis with probability value 0.1399 . This shows a bidirectional causality.

EF granger causes FDI, the null hypothesis is rejected as indicated by probability $0.0574(\mathrm{p}<0.10)$. But, FDI does not granger cause EF, we accept null hypothesis with probability value 0.7372 . This shows a uni-directional relationship between EF and FDI.

Hence, we will accept the null hypothesis $\mathrm{H}_{03}$ while we reject the alternate hypothesis.

As pictured from the causative relationship check, we will thus opine that the future value of Economic growth is 
dependent on the present value of FDI. Likewise, Economic Freedom future value is dependent on present value of FDI. This implies that the Federal government of Nigeria ought to take a massive step in guaranteeing there is correct connections among the variables adopted for this study so as that there will be a seamless process.

\section{Table VIII: Granger Causality Test Result}

Pairwise Granger Causality Tests

Sample: 19952018

Lags: 1

\begin{tabular}{lccl}
\hline \hline Null Hypothesis: & Obs & F-Statistic & Prob. \\
\hline \hline FDI does not Granger Cause LOGRGDP & 21 & 1.15727 & 0.2962 \\
LOGRGDP does not Granger Cause FDI & & 3.03584 & 0.0985 \\
\hline \hline EF does not Granger Cause LOGRGDP & 21 & 0.69433 & 0.4156 \\
LOGRGDP does not Granger Cause EF & & 2.38518 & 0.1399 \\
\hline \hline EF does not Granger Cause FDI & 21 & 4.11967 & 0.0574 \\
FDI does not Granger Cause EF & & 0.11610 & 0.7372 \\
\hline \hline
\end{tabular}

Source: Researcher's Computation from estimates ran on Eviews10

\section{CONCLUSION}

The study examined Foreign Direct Investment, Economic Freedom and Economic Growth of Nigeria. It therefore concludes that, FDI and Economic Freedom do not significantly affect Nigeria Economic Growth; also, FDI and Economic Freedom interactive effect is not significant on Nigeria economic growth. It was concluded that there exists causality between RGDP and FDI and between EF and FDI respectively.

Findings against each of the research objectives showed that;

- Economic Freedom and FDI do not significantly affect Nigeria Economic Growth

- FDI and Economic Freedom have no significant interactive effect on Economic Growth. However, there was a uni-directional relationship between RGDP and FDI and between EF and FDI respectively.

\section{RECOMMENDATIONS}

The following are recommended as a result of research findings:

i. Appropriate foreign trade strategies that will enhance FDI impact on economic growth in Nigeria should be adopted by the federal government.

ii. Policies for enhancing economic freedom should be put in place by the government as this has a way of impacting on economic growth of Nigeria. 
iii. Government should develop and maintain infrastructural facilities (like electricity, storage facilities, roads and water) so as to reduce the operational costs being run by foreign investors as this will enhance productivity and encourage other potential investors.

iv. Government policies should be reviewed at intervals and be flexible as this will aid foreign investment in Nigeria.

\section{CONFLICT OF INTEREST}

None

\section{REFERENCES}

Abu, O.G and Nurudeen, A. (2010). Determinants of FDI in Nigeria: An Empirical Analysis, Global Journal of Human Social Science. 10(1): 1-26.

Adegbemi, B. O. (2012). Foreign Direct Investment and Economic Growth in Nigeria: An Empirical Evidence. Journal of Applied Economics, 13(1): 31 - 49.

Ajide, K. B. (2014). Determinants of Economic Growth in Nigeria. CBN Journal of Applied Statistics, 5(2), 147-170.

Ajide, K. B., \& Eregha, P. B. (2015). Foreign Direct Investment, Economic Freedom and Economic Performance in Sub-Saharan Africa. Managing Global Transitions, 13(1), 43-57.

Agya Atabani, Amadi Kinsley Wobilor, Wunuji Emmanuel Adimani. (2015). Determinants of Foreign Direct Investment and Its Effect on Economic Growth. Journal of Economics and sustainable Development. ISSN 2222-1700 (paper) ISSN 2222-2855(online). Vol. 6, No. 20, 2015.

Akin, C. S., Aytun, C., \& Aktakas, B. G. (2014). The Impact of Economic Freedom Upon Economic Growth: An Application on Different Income Groups. Asian Economic and Financial Review, 4(8), 1024-1039.

Ariyo, A. (1998) “Investment and Nigeria's Economic growth". In Investment in the Growth Process Proceeddings of Nigerian Economic Society Annual Conference 1998, pp.389-415,Ibadan,Nigeria.

Athukorala, P., (2009). Trends and Patters of Foreign Direct Investment in Asia: A Comparative Perspective. MarginThe Journal of Applied Economic Research. 3(4): 365-408.

Ayal, E.B. and G. Karras (2008) Components of Economic Freedom and Growth: An Empirical Study. The Journal of Developing Areas, 32 (spring); 327-338.

Ayanwale, A. B (2007). FDI and Economic Growth: Evidence from Nigeria, AERC Research Paper 165, African Economic Research Consirtium, Nairobi.

Asiedu, E. (2012). On the Determinants of Foreign Direct Investment to Developing Countries: Is Africa Different? World Development 30(1): 107-118.

Banerjee, Anindya; et al. (1993). Co-Integration, Error Correction, and the Econometric Analysis of Non-Stationary Data. New York: Oxford University Press. pp. 266-268. ISBN 0-19-828810-7.

Barro, R. J. (2011). Economic Growth in a Cross Section of Countries, Quarterly Journal of Economics, 106, 407443.

Bayar, Y. (2016). Impact of Openness and Economic Freedoom on Economic Growth in the Transition Economies of 
the European Union. South-Eastern Europe Journal of Economics, 1, 7-19.

Becker, Gary S., Kevin M. Murphy, and Robert Tamura. 1990. Human capital, fertility and growth. Journal of Political Economy 98: S12-37.

Bellaouaied, M., \& Gam, A. (2012). Internal Marketing as a New Alternative for the Service Employees , Performance : An Empirical Study. Hal Archives-Ouvertes, 1-22.

Bengoa, M., and B. Sanchez Robles. (2003). "Foreign Direct Investment, Economic Freedom and Growth: New Evidence from Latin America. European Journal of Political Economics. 9(3): 529-45.

Breanth, A.A. (2006). Democracy and Growth, Journal of Economic Growth, 1, 1-27.

Campos, N.F. and Yuko K. (2013). Why Does FDI Go where it Goes? New Evidence from the Transition Economies. IMF Working Paper No WP/03/228. International Monetary Fund, Washington, D.C.

Carlsson, F. and Lundstrom, S. (2012). Economic Freedom and Growth: Decomposing the Effects, Public Choice, $112,335-344$.

Chen, Jen-Eem, and Azreen Mohd Zulkifli. 2012. Malaysian Outward FDI and Economic Growth. Procedia Social and Behavioral Sciences 65: 717-22.

Dawson, J. W. (2003). Causality in the Freedom-Growth Relationship, European Journal of Political Economy, 19, 479-495.

de Haan, Jakob, and Jan-Egbert Sturm. 2000. On the relationship between economic freedom and economic growth. European Journal of Political Economy 16: 215-41.

De Gregorio, J. (1992). Economic Growth in Latin America. Journal of Development Economics: 39, 58-84.

De Long, J. B. and Summers, L. H. (2011) Equipment Investment and Economic Growth, The Quarterly Journal of Economics, 106, 445-502.

Dollar, D. and Kraay, A. (2013). Institutions, Trade, and Growth, Journal of Monetary Economics, 50, 133-162.

Doucouliagos, Chris, and Mehmet Ali Ulubasoglu. 2006. Foreign direct investment. Economic freedom and economic growth: International evidence. European Journal of Political Economy 22: 60-81.

Ecuardo Borensztein, Jose De Gregorio, and Jong-Wha Lee (1998). Interaction of Economic Freedom and Foreign Direct Investment Globally. Journal of Economics and Financial Analysis, Vol: 1, No: 1 (2017) 59-80.

Egwuatu, C. (2007). "Foreign Direct Investment and the Nigerian Economy". An Unpublished, M.sc Thesis, Nnamdi Azikwe University, Akwa, 145pages.

Ekpo, A. H (2007). Determinants of Foreign Direct Investment in Nigeria: Evidence from Time Series Data, $C B N$ Economic and Finance Review, 35(1): 59-78.

Fairchild, A. J., \& Mackinnon, D. P. (2010). A General Model for Testing Mediation and Moderation Effects. Prev Sci., 10(2), 87-99. doi:10.1007/s11121-008-0109-6.A.

Favero, Carlo A. (2001). Applied Macroeconometrics. New York: Oxford University Press. pp. 56-71. ISBN 0-19829685-1.

Gastanaga, V., Nugent, J. and Pashamiova, B. (2008). Host Country Reforms and FDI Inflows: How Much Difference Do They Make? World Development, 26(7): 1299-1314. 
Goldsmith, A.A. (2005). Democracy, Property Rights and Economic Growth. The Journal of Development Studies, $32(2)$.

Gwartney, J.D., Lawson, R., and Holcombe, R.G. (2008). Economic Freedom and the Environment for Economic Growth. Journal of Institutional and Theoretical Economics, 155(2a): 643-663.

Haan, J. and Sturm, J.E. (2010). On the Relationship between Freedom and Economic Growth, European Journal of Political Economy 16, 215-241.

Hall and Jones (2009). Why Do Some Countries Produce So Much More Output Than Others? Quarterly Journal of Economics 114(1): 83-116.

Hatanaka, Michio (1996). Time-Series-Based Econometrics: Unit Roots and Cointegration. New York: Oxford University Press. pp. 219-246. ISBN 0-19-877353-6.

Heckelman, J. (2010). Economic Freedom and Economic Growth: A Short-run Causal Investigation, Journal of Applied Economics, III(I), 71-91.

Hussain, M. E., \& Haque, M. (2016). Impact of Economic Freedom on the Growth Rate: A Panel Data Analysis. Economics, 4(5), 1-15. http://doi.org/10.3390/economies4020005.

Islam, S. (2006) Economic Freedom, Per Capita Income and Economic Growth, Applied Economic Letters, 3(2): 595597.

Iyoha, M. A. (2011). An Econometric Study of the Main Determinants of Foreign Investment in Nigeria, The Nigerian Economic and Financial Review 6(2): 19-35.

Johansen, Soren. 1988. Statistical Analysis of Cointegration Vectors. Journal of Economic Dynamics and Control 12: 231-54.

Kairo, C. I., Mang, N. J., Okeke, A., \& Aondo, D. C. (2017). Government Expenditure and Human Capital Development in Nigeria: An Auto-Regressive Distributed Lagged Model Approach (ARDL). International Journal of Advanced Studies in Economics and Public Sector Management, 5(1), 143-158.

Knack, S. and Keefer, P. (2015). Institutions and Economic Performance: Cross Country Tests using Alternative Institutional Measures. Economics and Politics 7(1): 207-227.

Kneller, R., Bleaney, M. and Gemmell, B. (2009). Fiscal Policy and Growth: Evidence from OECD countries. Journal of Public Economics 74: 171-190.

Levine, R. and Renelt, D. (2012). A Sensitivity Analysis of Cross-country Growth Regressions, American Economic Review 82, 942-963.

Maddala, G. S.; Kim, In-Moo (1998). Unit Roots, Cointegration, and Structural Change. Cambridge University Press. pp. 198-248. ISBN 0-521-58782-4.

Minier, J. A. (2008) Democracy and Growth: Alternative Approaches, Journal of Economic Growth, 3, 241-266.

Monfort, K. (2002), "Easing the way for Foreign Direct Investment” Bank of Valleta Review, No. 26, Autum.

Nelson, M.A. and Singh, R.D. (2008). Democracy, Economic Freedom, Fiscal Policy and Growth in LDCs: A Fresh Look. Economic Development and Cultural Change 46; 677- 696.

Nwankwo, A. (2006), Determinant of FDI inflow in Nigeria. 6th Global Journal on Business and Economics, 2(9/8): 71-87. 
Oakley, J. L., \& Carolina, N. (2012). Bridging the Gap between Employees and Customers. Journal of Marketing Management, 28(9-10), 1094-1113.

Obadan, M.I. (2012). Direct Foreign Investment in Nigeria: An Empirical Analysis, African Studies Review, XXV (1) $9-23$.

Ogbonna, C. I., Uwajumogu, N. R., Nwokoye, E., \& Nzeribe, G. (2012). Economic Growth and Foreign Direct Investment in Nigeria: An Empirical Investigation. Journal of Economics and Sustainable Development, 3(13), 34-40.

Ogundipe, A., Adeniran, O. A., Bolaji-olutunji, K. A., Awodele, O. D., \& Aduradola, O. (2013). Agricultural Exports and Economic Growth in Nigeria (1980-2010). Journal of Economics and Sustainable Development, 4(16), $1-5$.

Olugbenga, A. O., \& Owoye, O. (2007). Public Expenditure and Economic Growth: New Evidence from OECD Countries. IAES.

Omowumi, O. I. and Abel A.A. (2014). Foreign Direct Investment in Nigeria, International Journal of Liberal Arts and Social Science 2(9): 71-87 ISSN: 2307-924X.

Oteng-Abayie, E. F. (2011). Government Expenditure and Economic Growth in Five ECOWAS Countries: A Panel Econometric Estimation, Journal of Economic Theory, 2(3): 11-14.

Panahi, H., Assadzadeh, A., \& Refaei, R. (2014). Economic Freedom and Economic Growth in Mena Countries. Asian Economic and Financial Review, 4(1), 105-116.

Pan-Long, W. (2014). Determinant of Foreign Direct Investment and Its impacts on Economic Growth, Journal of Economic Development, 19(1): 137-163.

Pham, T. (2009). Government Expenditure and Economic Growth: Evidence from Singapore, Hong Kong, China and Malaysia. Rotterdam: Erasmus University.

Preacher, K. J., \& Hayes, A. F. (2004). SPSS and SAS Procedures for Estimating Indirect Effects in Simple Mediation Models. Behaviour Research Methods, Instruments \& Computers, 36(4), 717-731.

Ram, R. (2006). Government Size and Economic Growth: A New Framework and Some Evidence from Cross-Section and Time Series Data. American Economic Review, 2(1): 191-203.

Sala-i-Martin, X., Doppelhofer, G., and Miller, R. I. (2014). Determinants of Long-term Growth: Bayesian Averaging of Classical Estimates (BACE) Approach, American Economic Review, 94, 813-835.

Sayari, Naz, Sari Ramazan, and Shawkat Hammoudeh. 2018. The impact of value added components of GDP and FDI on economic freedom in Europe. Economic Systems 42: 282-94.

Schoeman, N., Robinson, J., Clausen, Z. and DeWet, T. J. (2010). Foreign Direct Investment Flows and Fiscal Discipline in South Africa, South African Journal of Economic and Management Sciences, 3(2): 35- 44.

Seitz, W.O. (2010). On the Relationship between Economic Freedom and Economic Growth, European Journal of Political Economy, 16, 215-246.

Singh, H. and Jun, K.W. (2005), Some New Evidence on Determinants of Foreign Direct Investment in Developing Countries. Policy Research Working Paper No.1531. The World Bank.

Sovbetov, Y., \& Moussa, M. (2017). Interaction of Economic Freedom and Foreign Direct Investment Globally: Special Cases from Neglected Regions. Journal of Economics and Financial Analysis, 1(1), 59-80. http://doi.org/10.1991/jefa.v1i1. 
Sturm, J.E. and de Haan, J. (2011). How Robust is the Relationship between Economic Freedom and Economic Growth, Applied Economics, 33(4): 839-844

Tavares, J. and Wacziarg, R. (2011). How Democracy Affects Growth, European Economic Review, 45, 1341-1378.

Thoumrungroje, A., \& Racela, O. (2013). The Contingent Role of Customer Orientation and Entrepreneurial Orientation on Product Innovation and Performance. Journal of Strategic Marketing, 21(2), 140-159. doi:10.1080/0965254X.2012.742129.

Ubeda, Fernando, and Francisco Pérez-Hernández. 2017. Absorptive Capacity and Geographical Distance Two Mediating Factors of FDI Spillovers: A Threshold Regression Analysis for Spanish Firms. Journal of Industry, Competition and Trade 17: 1-28.

Udeajah, E.A. (2011), “The Investment Climate in Nigeria: Prospect and Challenges". Journal of Economic Studies, 5(1): 20-25.

Udoh, E and Egwaikhide, F. O (2008). Exchange Rate Volatility, Inflation Uncertainty and Foreign Direct Investment in Nigeria, Botswana Journal of Economics, 5(7): 14-31.

Uremadu, S. O., Umezurike, I. N., \& Odili, O. (2016). Impact of Foreign Direct Investment on the Economy of Nigeria. Research Journal of Finance and Accounting, 7(11), 31-43.

Vanssay, X. and Spindler, Z.A. (2014). Freedom and Growth: Do Constitutions Matter? Public Choice 78: 359-372.

Zghidi, N., Sghaier, I.M., and Abida, Z. (2016). Does economic Freedom Enhance the Impact of Foreign Direct Investment on Economic Growth in North Africa Countries? A Panel Data Analysis, African Development Review, 28(1): $64-74$. 